\title{
Performance of colloidal CdS sensitized solar cells with ZnO nanorods/nanoparticles
}

\author{
Anurag Roy ${ }^{1,2}$, Partha Pratim Das ${ }^{1,2}$, Mukta Tathavadekar ${ }^{2,3}$, Sumita Das ${ }^{1}$ \\ and Parukuttyamma Sujatha Devi ${ }^{* 1,2, \S}$
}

\author{
Full Research Paper \\ Address: \\ ${ }^{1}$ Sensor and Actuator Division, CSIR - Central Glass and Ceramic \\ Research Institute, Kolkata 700032, India, ${ }^{2} \mathrm{CSIR}$ - Network Institute \\ of Solar Energy (CSIR-NISE), New Delhi, India, and ${ }^{3}$ Physical and \\ Materials Chemistry Division, CSIR-National Chemical Laboratory, \\ Pune 411 008, India \\ Email: \\ Parukuttyamma Sujatha Devi - psujathadevi@cgcri.res.in \\ * Corresponding author \\ § Tel.: +91-33-2483-8082; Fax: +91-33-2473-0957 \\ Keywords: \\ DSSC; QDSSC; quantum dot; solar cells; ZnO \\ Beilstein J. Nanotechnol. 2017, 8, 210-221. \\ doi:10.3762/bjnano.8.23 \\ Received: 06 August 2016 \\ Accepted: 19 November 2016 \\ Published: 23 January 2017 \\ Associate Editor: R. Naaman \\ (c) 2017 Roy et al.; licensee Beilstein-Institut. \\ License and terms: see end of document.
}

\begin{abstract}
As an alternative photosensitizer in dye-sensitized solar cells, bovine serum albumin (BSA) (a nonhazardous protein) was used in the synthesis of colloidal CdS nanoparticles (NPs). This system has been employed to replace the commonly used N719 dye molecule. Various nanostructured forms of $\mathrm{ZnO}$, namely, nanorod and nanoparticle-based photoanodes, have been sensitized with colloidal CdS NPs to evaluate their effective performance towards quantum dot sensitized solar cells (QDSSCs). A polysulphide $\left(\mathrm{S}_{x}{ }^{2-}\right)$-based electrolyte and $\mathrm{Cu}_{x} \mathrm{~S}$ counter electrode were used for cell fabrication and testing. An interesting improvement in the performance of the device by imposing nanorods as a scattering layer on a particle layer has been observed. As a consequence, a maximum conversion efficiency of $1.06 \%$ with an open-circuit voltage $\left(V_{\mathrm{OC}}\right)$ of $0.67 \mathrm{~V}$ was achieved for the $\mathrm{ZnO}$ nanorod/nanoparticle assembled structure. The introduction of $\mathrm{ZnO}$ nanorods over the nanoparticle led to a significant enhancement of the overall efficiency compared to the corresponding bare nanoparticles.
\end{abstract}

\section{Introduction}

Dye-sensitized solar cells (DSSCs) using inorganic semiconductors are being investigated as a cost-effective and alternative energy source. In DSSCs, a porous electrode made of a wide band gap semiconductor is required for anchoring dye molecules and transporting photo-injected electrons. Commonly used dye molecules are Ru-based N719 and N3. However, recently, chalcogenide semiconductors such as $\mathrm{CdS}, \mathrm{InP}, \mathrm{CdSe}$,
$\mathrm{PbS}, \mathrm{CdSe}, \mathrm{Sb}_{2} \mathrm{~S}_{3}$ have been explored for replacing the sensitizers in DSSC [1-4]. Thus, there has been a renewed interest in the area of DSSC, resulting in the development of the so-called quantum dot sensitized solar cells (QDSSCs) [5-9]. Due to its natural abundance and comparatively lower cost, $\mathrm{CdS}$, one of the important direct band II-VI semiconductors with a band gap of $\approx 2.4 \mathrm{eV}$, has been investigated for this purpose. According to 
the reported results, CdS-sensitized ZnO QDSSCs exhibit a wide range of efficiencies ranging from 0.06 to $\approx 4 \%$ depending on the photoanode, processing technique and sensitizing mechanism [10-16]. For example, in a pioneering study by Liu et al., $1.40 \%$ efficiency was reported with an open-circuit voltage $\left(V_{\mathrm{OC}}\right)$ of $0.62 \mathrm{~V}$ by using hierarchically structured $\mathrm{ZnO}$ [11]. A recent study by Poornima et al., on the other hand, reported a slightly higher efficiency of $1.59 \%$ with a $V_{\text {OC }}$ of 0.74 for $\mathrm{Cu}$-doped $\mathrm{ZnO}$ [12]. Many others reported comparatively poorer efficiencies of $0.067 \%$ and $0.87 \%$ along with lower $V_{\mathrm{OC}}$ of 0.20 and $0.54 \mathrm{~V}$, respectively [10,13]. Interestingly, in all the above cases, the successive ion-layer absorption and reaction (SILAR) process has been used as the sensitization process for QD sensitization. In addition to SILAR, chemical bath deposition (CBD) has also been used as a CdS sensitization technique. Respective efficiencies of $0.87 \%$ and $0.72 \%$ with $V_{\mathrm{OC}}$ of $0.44 \mathrm{~V}$ and $0.55 \mathrm{~V}$, have been reported by Zhang et al. and Qi et al., for $\mathrm{ZnO}$ nanowires which are noteworthy reports $[14,15]$. For QDSSCs, a polysulphide electrolyte/ $\mathrm{Cu}_{2} \mathrm{~S}$ electrode delivered the best performance instead of the regular $\mathrm{I}^{-} / \mathrm{I}_{3}{ }^{-}$electrolyte with a costly Pt-based electrode.

Reports on the synthesis of nanoscale CdS by using organic capping agents, polymers, surfactants, or enzymes reveal that they are not very user friendly techniques [17-23]. Therefore, rather taking a conventional path to synthesizing quantum dots (QDs) we followed a bioinspired strategy to synthesize such systems. In this work, bovine serum albumin (BSA) is selected as a biotemplating agent. BSA is a ubiquitous protein mainly present in blood and is a commonly used reagent in biological studies. Here, we have synthesized functionalized colloidal CdS nanoparticles (NPs) by a sono-chemical synthesis using BSA as a biotemplate [24-26]. BSA can construct surface functionalized colloidal CdS QDs with modified optical properties as compared to its bulk form. This can further be employed to render stable dispersion of CdS NPs without nanoparticle aggregation. Various disulfide bonds, thiol residues and other hydroxyl moieties that exist on BSA can serve as effective surface functionalized groups on CdS surfaces [27]. This may further lead to better anchoring with the metal oxide-based photoanode. Among the alternative single oxide materials investigated so far, $\mathrm{ZnO}$ delivers effective performance owing to higher band gap $(\approx 3.3 \mathrm{eV})$ and high electron mobility $\left(\approx 200-300 \mathrm{~cm}^{2} \mathrm{~V}^{-1} \mathrm{~S}^{-1}\right)$ compared to conventional $\mathrm{TiO}_{2}$ $[28,29]$. Also, the flexibility in morphological control and the possibility of low-temperature applications also indicates that $\mathrm{ZnO}$ could be a preferential alternative to $\mathrm{TiO}_{2}$. However, $\mathrm{ZnO}$ suffers from lack of stability in the acidic Ru-based sensitizers in DSSCs, leading to the formation $\mathrm{ZnO}$ /dye aggregates [30]. This can be easily avoided for QDSSCs where the used sensitizer, $\mathrm{CdS}$, is neutral in nature. In our earlier work, we have re- ported the advantages of using $1 \mathrm{D} \mathrm{ZnO}$ nanorods compared to nanoparticles in DSSCs using N719 as a photosensitizer [31]. Due to the reduced grain boundaries and direct conjunction pathway, 1D nanorods can diffuse electrons faster than nanoparticles and other morphologies. However, nanoparticles lead to higher surface area than 1D nanorods which can sensitize more CdS at a particular time. In this study, we have used synthesized $\mathrm{ZnO}$-based photoanodes exhibiting two different morphologies: $\mathrm{ZnO}$ nanoparticles ( $\mathrm{ZnO}-\mathrm{P})$ and nanorods ( $\mathrm{ZnO}-\mathrm{R})$ for fabricating QDSSCs. We evaluated their respective performance after sensitization with colloidal CdS. In addition, by using $1 \mathrm{D} \mathrm{ZnO}$ nanorods as a scattering layer, improved photovoltaic activity of $\mathrm{ZnO}$ upon sensitization with colloidal $\mathrm{CdS}$ could be achieved [32,33].

\section{Experimental Materials}

The raw material used for the synthesis of $\mathrm{Cd}\left(\mathrm{NO}_{3}\right)_{2}, 3 \mathrm{H}_{2} \mathrm{O}$, $\mathrm{Na}_{2} \mathrm{~S} \cdot 7 \mathrm{H}_{2} \mathrm{O}$ and ethanol were purchased from Merck Limited, Germany. Bovine serum albumin was purchased from SigmaAldrich, USA. $\mathrm{Zn}\left(\mathrm{NO}_{3}\right)_{3}$ and $\mathrm{Zn}\left(\mathrm{CH}_{3} \mathrm{COO}\right)_{2}$ were purchased from Merck Limited, Germany. All the chemicals were used without any further purification.

\section{Synthesis of CdS nanoparticles}

The CdS NPs were synthesized using a BSA-mediated process under sonication. Aqueous solutions of $0.1 \mathrm{M} \mathrm{Cd}\left(\mathrm{NO}_{3}\right)_{2} \cdot 4 \mathrm{H}_{2} \mathrm{O}$ and $1.25 \times 10^{-6} \mathrm{M}(\mathrm{BSA})$ were sonicated (ultrasonic probe, Rivotek, $30 \mathrm{kHz}, 250 \mathrm{~W}$ ) for $45 \mathrm{~min}$ followed by immediate dropwise addition of $0.1 \mathrm{M} \mathrm{Na}_{2} \mathrm{~S}$ until the $\mathrm{pH}$ of the resultant solution reached $\approx 4$. The sonication was continued for $1.5 \mathrm{~h}$. The yellowish-orange precipitate was centrifuged at 10,000 rpm followed by thoroughly washing with ethanol and distilled water. The precipitate was further dried at $70{ }^{\circ} \mathrm{C}$ and calcined at $300{ }^{\circ} \mathrm{C}$ for $2 \mathrm{~h}$. The resultant yellowish-orange powder was used for further studies. $\mathrm{ZnO}$ nanoparticles and nanorods were synthesized by a solution-growth process, the details of which are reported elsewhere [31,32].

\section{Fabrication of CdS-NP-sensitized ZnO-based films}

$\mathrm{ZnO}$ nanoparticle $(\mathrm{ZnO}-\mathrm{P})$ and nanorod $(\mathrm{ZnO}-\mathrm{R})$ films were fabricated by the doctor blade method on FTO glass $\left(7 \Omega / \mathrm{cm}^{2}\right)$ and annealed at $450{ }^{\circ} \mathrm{C}$ for $30 \mathrm{~min}$. In addition, a $\mathrm{ZnO}-\mathrm{R}$ layer was deposited over the $\mathrm{ZnO}-\mathrm{P}$ layer to fabricate a $\mathrm{ZnO}$ nanoparticle/rod ( $\mathrm{ZnO}-\mathrm{P}+\mathrm{R})$ assembled film. For making CdS coatings on the $\mathrm{ZnO}$ photoanode films by $\mathrm{CBD}$ process, the fabricated films were dipped in $0.5 \mathrm{M}$ of synthesized colloidal CdS dispersion in ethanol ( $\mathrm{pH}$ 6.4) for $18 \mathrm{~h}$ under constant stirring at room temperature. Subsequently, the fabricated films were thoroughly washed with ethanol and dried at $60{ }^{\circ} \mathrm{C}$. The fabricated photonaode films were further employed for in-situ CdS sensiti- 
zation by the SILAR process. Here, the films were successively dipped in $0.1 \mathrm{M} \mathrm{Cd}\left(\mathrm{NO}_{3}\right)_{2}$ and $0.1 \mathrm{M} \mathrm{Na}_{2} \mathrm{~S}$ solution in ethanol for $30 \mathrm{~s}$. The cycle was repeated five times and finally the CdS deposited films were thoroughly washed with ethanol. An effective area of $0.25 \mathrm{~cm}^{2}(0.5 \times 0.5 \mathrm{~cm})$ was selected for measurement with proper sealing. Two different types of electrolytes were used for the cell fabrication, such as polysulphide and iodine/iodide. The electrolyte solution was prepared with $0.5 \mathrm{M} \mathrm{Na}_{2} \mathrm{~S}, 1 \mathrm{M} \mathrm{S}$ and $0.02 \mathrm{M} \mathrm{KCl}$ in ethanol: water mixture (7:3) solution. In addition, to fabricate the counter electrode, a $0.1 \mathrm{M} \mathrm{Cu}\left(\mathrm{NO}_{3}\right)_{2}$ solution in ethanol was drop-casted followed by $0.05 \mathrm{M} \mathrm{Na}_{2} \mathrm{~S}$ solution in ethanol on the FTO glass $\left(7 \Omega / \mathrm{cm}^{2}\right)$ and fired at $420^{\circ} \mathrm{C}$ for $20 \mathrm{~min}$. [34,35]. In some cases, a platinum counter electrode was also used.

\section{Characterization of CdS NPs}

The structural properties of dried CdS powder were characterized using X-ray diffraction (XRD) analysis on an X'pert pro MPD X-ray diffractometer by PANanalytical with $\mathrm{Cu} \mathrm{K} \alpha$ radiation $(\lambda=1.5406 \AA)$. Fourier transform-infrared (FT-IR) spectra were measured between 4000 and $400 \mathrm{~cm}^{-1}$ on a Perkin Elmer, Spectrum Two FT-IR spectrometer with a resolution of $4 \mathrm{~cm}^{-1}$ on the dried powder using potassium bromide (FTIR grade $\geq 99 \%$ trace metal basis, Sigma-Aldrich). The as-received $\mathrm{KBr}$ was oven-dried overnight at $\approx 100{ }^{\circ} \mathrm{C}$ and then stored in a desiccator prior to use. Furthermore, the Raman spectrum was collected using a $514.5 \mathrm{~nm} \mathrm{Ar}{ }^{+}$green laser excitation source with $50 \mathrm{~mW}$ power on a STR500, Cornes Technologies system. The ethanol dispersion of the synthesized CdS was used to measure the absorption spectrum on a UV-vis-NIR spectrophotometer (Shimadzu, UV-3600). The emission spectra of the same dispersion was recorded on a steady-state spectrofluorometer (QM-40, Photon Technology International) using a Xe lamp $(150 \mathrm{~W})$ as an excitation source with a bandpass of $5 \mathrm{~nm}$ at room temperature. The fluorescence quantum yield of the colloidal CdS solution was measured on the steady state fluorometer using an additional integrating sphere [32]. Zeta potential measurements were carried out on a Horiba Nanoparticle Analyzer-SZ100. The morphology of the synthesized powder was monitored on a transmission electron microscope (TEM) with a Tecnai G2 30ST (FEI) high-resolution TEM operating at $300 \mathrm{kV}$.

\section{Characterization and performance evaluation of CdS-sensitized $\mathrm{ZnO}-\mathrm{R}$ and $\mathrm{ZnO}-\mathrm{P}$ films}

The fabricated films were characterized by structural evaluation using X-ray diffraction analysis on an X'pert pro MPD $\mathrm{XRD}$ from PANanalytical with $\mathrm{Cu} \mathrm{K} \alpha$ radiation. The microstructural study and cross-sectional thickness of the fabricated films were monitored on a scanning electron microscope (SEM) (LEO 430i, Carl Zeiss). Diffuse reflectance spectra were measured on a UV-vis-NIR spectrometer (Shimadzu, UV-3600) on the considered films. Contact angle (CA) measurements were performed on a KRUSS Drop Shape Analyser, Germany (DSA-4). The photovoltaic $J-V$ characteristics were measured using a solar simulator (Newport) at $100 \mathrm{~mW} / \mathrm{cm}^{2}$ (1 sun AM 1.5). A standard silicon solar cell (serial number 189/PVM351) from Newport, U.S. was used as a reference cell. The active area of the fabricated cells used for photovoltaic measurement was $0.25 \mathrm{~cm}^{2}$. Further, the $I-V$ characteristics under normal light on CdS-sensitized $\mathrm{ZnO}$ films were measured using an Agilent two-channel precision source and measurement unit (model no. B2902A).

\section{Results and Discussion Structural and microstructural studies of CdS NPs}

The XRD pattern of the synthesized CdS NPs is shown in Figure 1a. All the peaks were well-indexed and matched with the cubic phase of CdS, corresponding to the JCPDS card number 42-1411. Furthermore, the lattice constant was calculated to be $5.585 \AA$ which again matches with the reported value. The broadness as well as intensity of the peaks of the XRD reflections indicates the smaller size of the formed nanoparticles. The mean size of the crystallites was calculated to be $\approx 5.2 \mathrm{~nm}$ using the Scherrer equation. The bright field image of the synthesized powder indicated the finer and porous nature of the synthesized CdS nanoparticles (Figure 1b). The high resolution TEM (HRTEM) image shows the (111) and (311) crystalline planes with $d$ values of $0.338 \mathrm{~nm}$ and $0.178 \mathrm{~nm}$, respectively, of cubic $\mathrm{CdS}$ as shown in Figure 1c. The corresponding FFT pattern is shown in the inset of the figure. The selected area diffraction (SAED) pattern also indicated the major crystalline planes (311), (220) and (111) of cubic CdS as shown in Figure 1d. A quantitative elemental energy dispersive X-ray (EDAX) analysis was performed and the results are given in Supporting Information File 1, Figure S1, to further confirm the formation of CdS.

\section{Spectroscopic analysis of CdS NPs}

The FTIR spectrum of the synthesized CdS NPs is shown in Figure $2 \mathrm{a}$. The band at $621 \mathrm{~cm}^{-1}$ corresponds to the $\mathrm{Cd}-\mathrm{S}$ stretching mode. Moreover, the bands assigned at 1110 and $1621 \mathrm{~cm}^{-1}$ are attributed to the $\mathrm{C}-\mathrm{S}, \mathrm{S}-\mathrm{H}$ and $\mathrm{C}-\mathrm{O}$ stretching modes, corresponding to the surface functionalized CdS NPs, whereas the band at $3480 \mathrm{~cm}^{-1}$ is responsible for labile $-\mathrm{OH}$ stretching due to surface adsorbed water [36]. The surface-functionalized CdS acts as an anchoring moiety, which promotes CdS towards effective sensitization with $\mathrm{ZnO}$. The Raman spectrum was performed as shown in Figure $2 b$. The peaks located at 294 and $589 \mathrm{~cm}^{-1}$ correspond to the fundamental band (1LO) and corresponding overtone (2LO) of longitudinal optical (LO) 


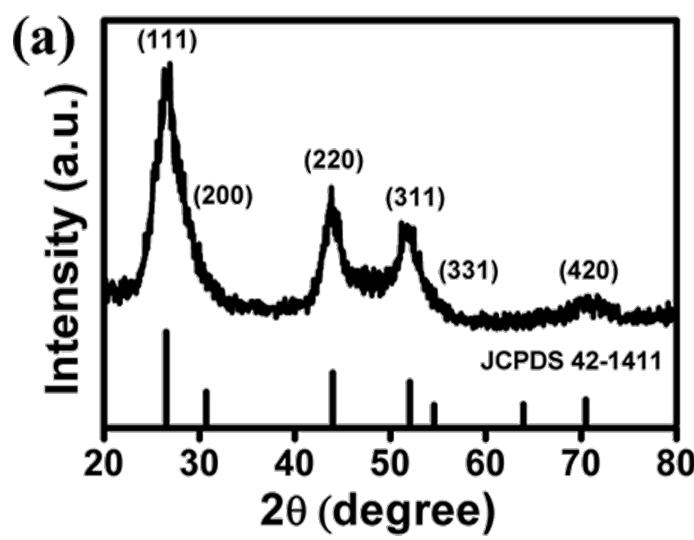

(b)

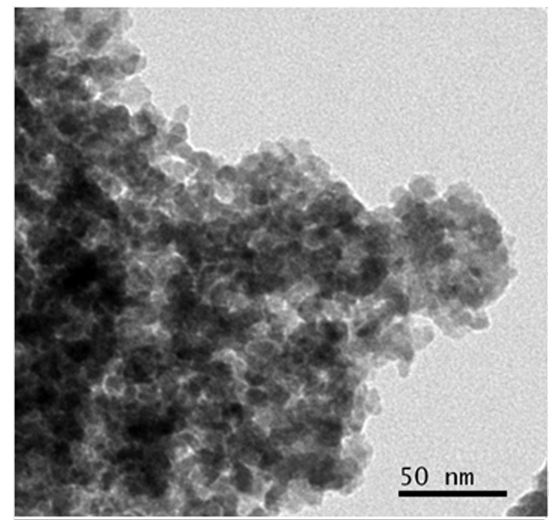

(c)

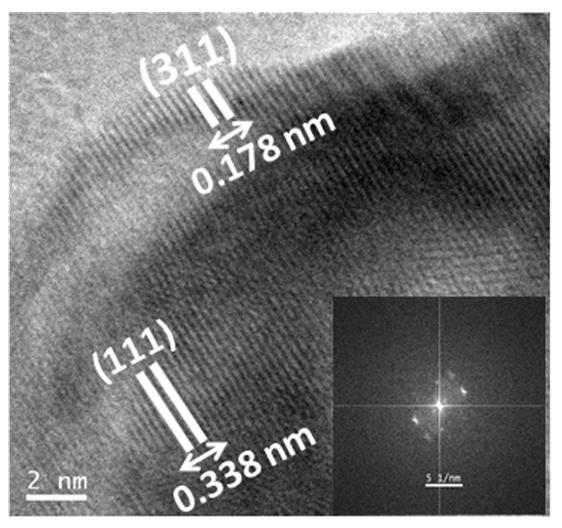

(d)

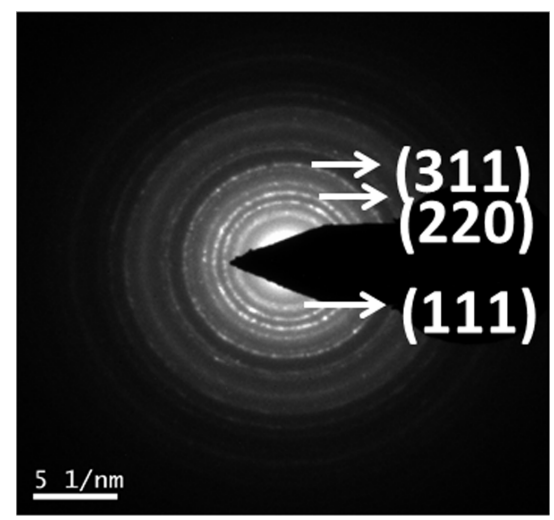

Figure 1: (a) Powder X-ray diffraction pattern of the synthesized cubic CdS powder along with standard JCPDS card no. 42-1411. (b) Bright field transmission electron microscope image of the NPs. (c) HRTEM image highlighting the inter-planar distance of the cubic crystal planes (Inset: corresponding FFT pattern). (d) SAED pattern from image in (b).

phonon modes of CdS, respectively. The peak $876 \mathrm{~cm}^{-1}$ is assigned to a combination of (1LO + 2LO) [37,38].

The UV-vis absorption spectrum of CdS NPs exhibited an absorption edge $\left(\lambda_{\mathrm{e}}\right)$ at $\approx 480 \mathrm{~nm}$ (Figure $2 \mathrm{c}$ ) which further depicted an average nanoparticle size of $4.71 \mathrm{~nm}$ as derived from Henglein's empirical equation [39]. The corresponding optical band gap was calculated to be $2.33 \mathrm{eV}$ from the Tauc plot, considering allowed direct transition for synthesized CdS NPs (inset of Figure 2c). The emission spectrum of CdS NPs was monitored at room temperature by varying the excitation wavelength from 340 to $390 \mathrm{~nm}$, as shown in Figure 2d. A green emission at $536 \mathrm{~nm}$ was observed against all the excitation wavelengths. The intensity of the emission band was maximum at the excitation wavelength of $390 \mathrm{~nm}$. The solution of synthesized CdS in ethanol resulted in a quantum yield (QY) of $3.116 \%$ at room temperature. This is an indication of the ratio of the number of fluorescence quanta to the number of absorbed quanta which is directly proportional to the fluorescence lifetime. Zeta potential $(\zeta)$ measurements were also carried out to verify the stability of the CdS NPs in ethanol. A zeta potential value of $-38.8 \mathrm{mV}$ (as shown in Supporting Infor- mation File 1, Figure S2) illustrates the excellent stability of the dispersion as required for the sensitization resulting in a colloidal solution [40].

\section{Structural and optical study of CdS films}

In order to characterize the CdS NPs sensitized on different $\mathrm{ZnO}$ films, the X-ray diffraction and diffuse reflection studies of the films were performed. The appearance of the cubic phase of CdS along with expected hexagonal $\mathrm{ZnO}$ phase confirms effective sensitization of $\mathrm{CdS}$ over $\mathrm{ZnO}$ (Figure 3a). This further demonstrates the stability of formed $\mathrm{CdS}$ even after the sensitization on the photoanode. It is also interesting to notice the increased intensity of X-ray reflections of CdS after sensitization over ZnO-P compared to $\mathrm{ZnO}-\mathrm{R}$. The relatively lower reflectance spectrum of the CdS-sensitized ZnO-P illustrates a better CdS sensitization phenomenon and corroborates the XRD analysis, as shown in Figure 3b. Further investigation of contact angle (CA) measurements by using $\mathrm{CdS}$ dispersions on $\mathrm{ZnO}$-based films justifies the sensitization capability. The reduced CA value of $19.6^{\circ}$ for the film fabricated with $\mathrm{ZnO}-\mathrm{P}$ further ascertains its better $\mathrm{CdS}$ affinity whereas a moderate $\mathrm{CA}$ value of $53.5^{\circ}$ was observed for $\mathrm{ZnO}-\mathrm{R}$, as shown in Figure 3c. 
(a)

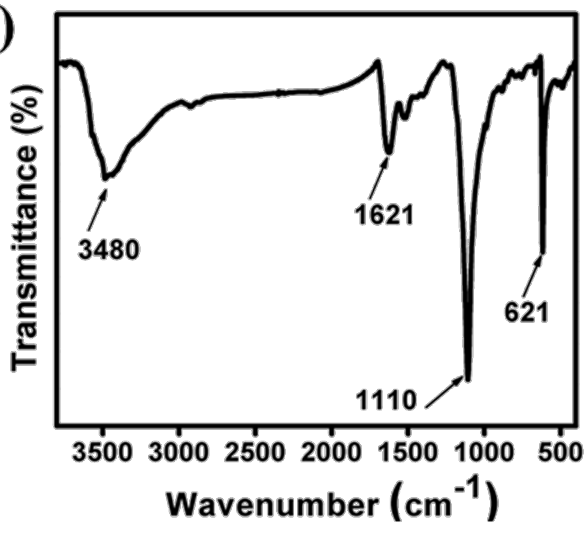

(c)

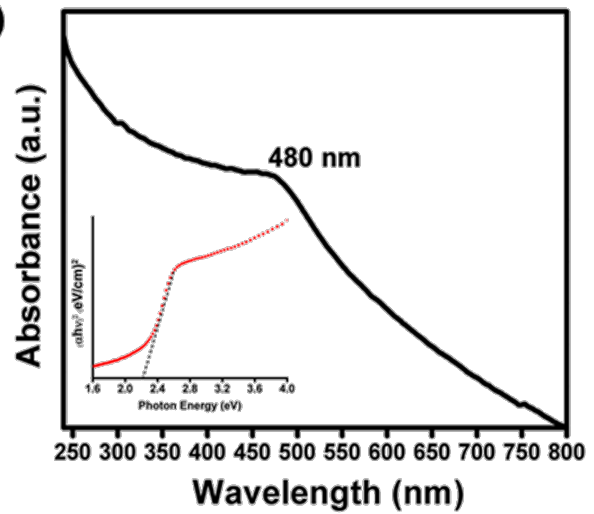

(b)

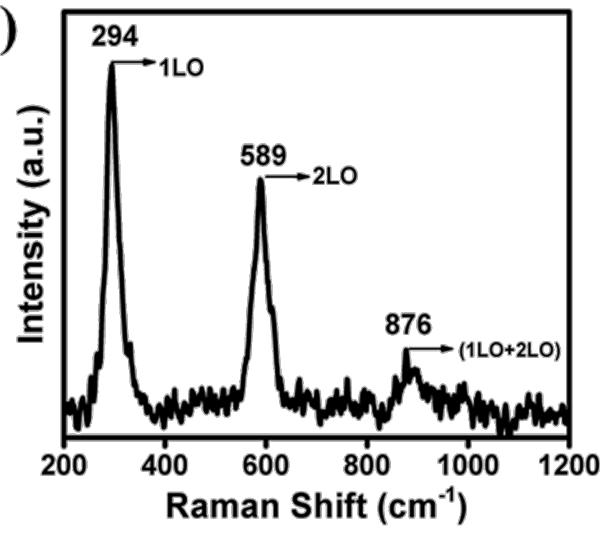

(d)

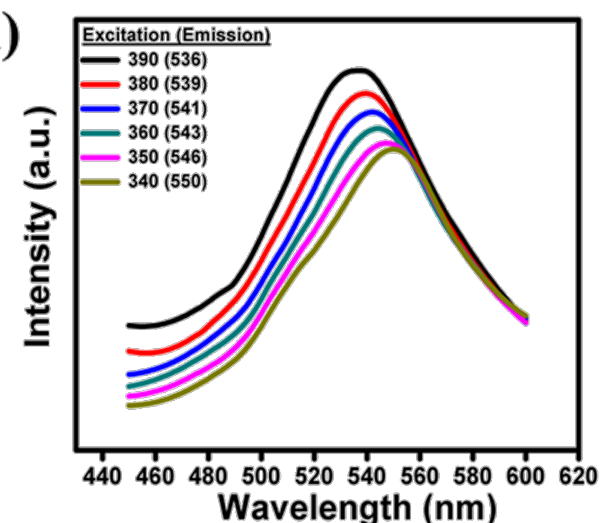

Figure 2: (a) and (b) show the FT-IR and Raman spectrum, respectively, of the synthesized CdS NPs. (c) UV-vis absorption spectrum (Inset: corresponding Tauc Plot for optical band gap measurement) and (d) excitation wavelength dependent emission spectra of the CdS NP dispersion at room temperature.
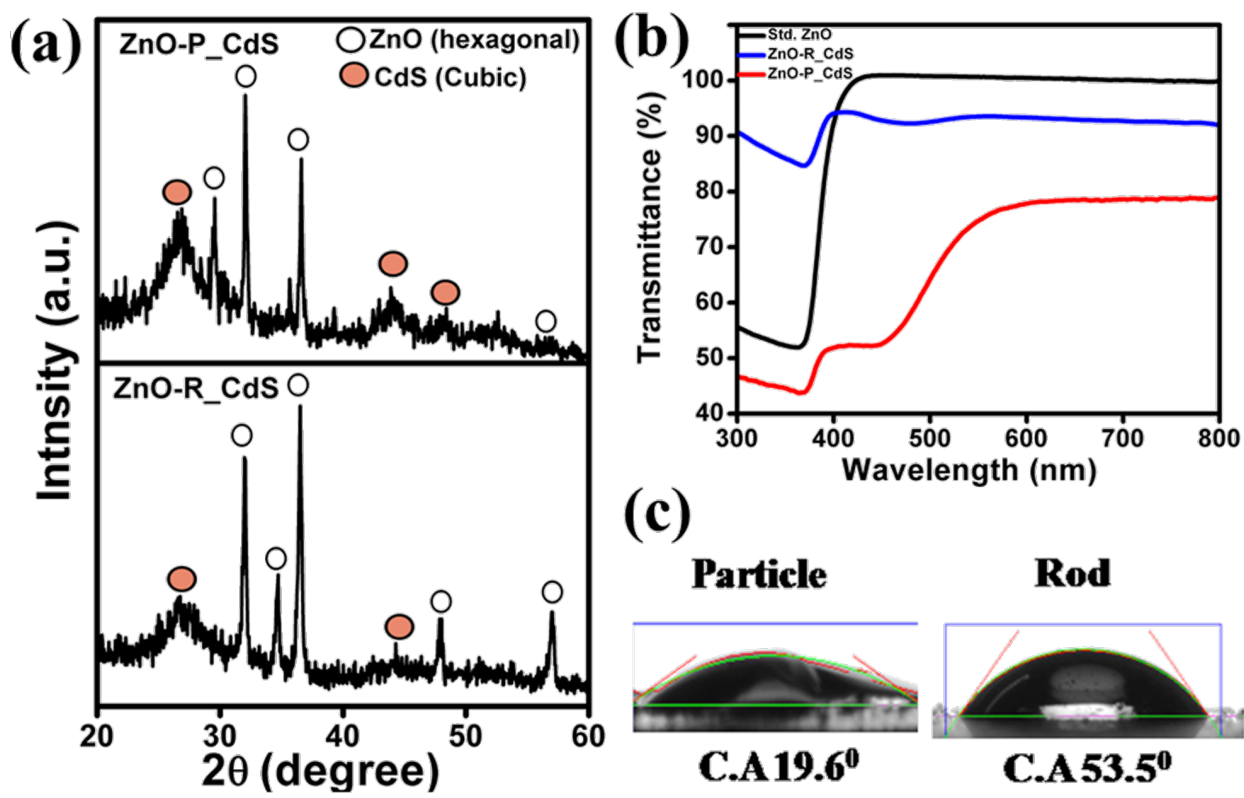

(c)
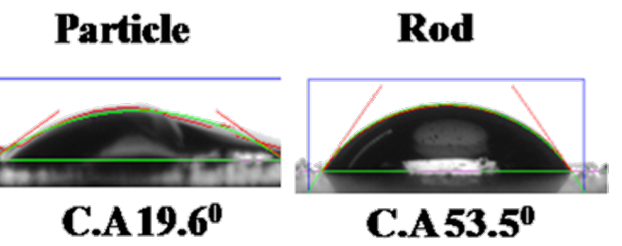

Figure 3: (a) Respective X-ray diffraction patterns of the CdS-sensitized ZnO-P and ZnO-R films. (b) Diffuse reflectance spectrum of the same films compared to bare $\mathrm{ZnO}$ and (c) a digital image showing the difference in contact angle for ethanolic solution of N719 dye for $\mathrm{ZnO}-\mathrm{R}$ and $\mathrm{ZnO}-\mathrm{P}$ films 
The higher surface area of ZnO-P facilitates better CdS sensitization compared to the rod-shaped $\mathrm{ZnO}$, having low surface area and rough surface characteristics. In order to establish the deposition of CdS over ZnO-based films, the FESEM images of the sensitized films fabricated on $\mathrm{ZnO}-\mathrm{P}$ and $\mathrm{ZnO}-\mathrm{R}$ were monitored as depicted in Figure 4. The microstructural FESEM and TEM bright field images of the synthesized $\mathrm{ZnO}-\mathrm{R}$ and $\mathrm{ZnO}-\mathrm{P}$ are shown in Figure 4. The average nanoparticle size of the $\mathrm{ZnO}-\mathrm{P}$ was calculated to be $\approx 12 \mathrm{~nm}$ from TEM. It is evident from the SEM images that the formation of $\mathrm{ZnO}$ nanorods in the as-prepared stage have an average length of $\approx 4 \mu \mathrm{m}$ and a range of diameters between $50-200 \mathrm{~nm}$.

The microstructural images in Figure 5a,c manifest the successful deposition of CdS NPs over the ZnO films. The crosssectional FESEM images of ZnO-P and ZnO-R films revealed a thickness of $\approx 11 \mu \mathrm{m}$ and $\approx 9 \mu \mathrm{m}$, respectively, as shown in Figure $5 \mathrm{~b}$,d. The aggregation of $\mathrm{ZnO}-\mathrm{P}$ helped in increasing the film thickness to some extent compared to $\mathrm{ZnO}-\mathrm{R}$ having irregular orientation. It is worth noting the homogeneous growth of both nanoparticle and nanorod-based nanostructures of $\mathrm{ZnO}$ on the FTO surface.
The FESEM elemental mapping with distinct color contrast along with line scale mapping were recorded on the sensitized films as shown in Figure 6a,b for the CdS-ZnO-P and CdS$\mathrm{ZnO}-\mathrm{R}$ samples, respectively. The homogeneous distribution of $\mathrm{Zn}$ and $\mathrm{O}$ followed by the coating of $\mathrm{CdS}$ is very clear from the elemental mapping diagram. The presence of more $\mathrm{CdS}$ is clear on the $\mathrm{ZnO}-\mathrm{P}$ surface compared to the $\mathrm{ZnO}-\mathrm{R}$ surface. This confirms the homogeneous distribution of $\mathrm{CdS}$ throughout the $\mathrm{ZnO}$ surface as illustrated in Figure 6a,b.

\section{Performance of the fabricated solar cells}

The films fabricated with $\mathrm{ZnO}-\mathrm{P}$ and $\mathrm{ZnO}-\mathrm{R}$ as the photoanode followed by sensitization with CdS NPs was further characterized by $J-V$ measurements as shown in Figure 7. ZnO-P based cells exhibited an overall conversion efficiency of $0.34 \%$. In spite of higher CdS sensitization, the undesired agglomeration forms more interparticle gaps. This leads to the higher possibility of electron recombination and entrapment resulting in poor photovoltaic performance for particles. On the contrary, the multioriented 1D ZnO nanorods promote better light harvesting and faster electron injection, resulting in modest improvement in short circuit current $\left(J_{\mathrm{SC}}\right)$ as well as fill factor $(\mathrm{FF})$ with an (a)

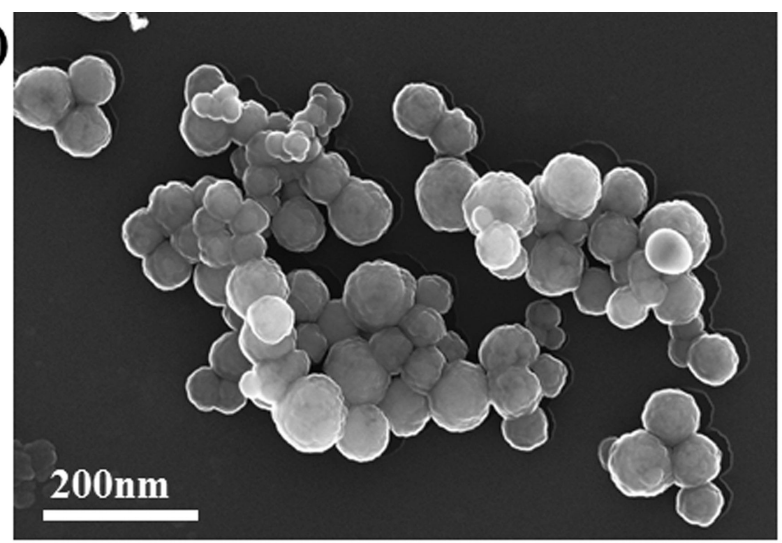

(c)

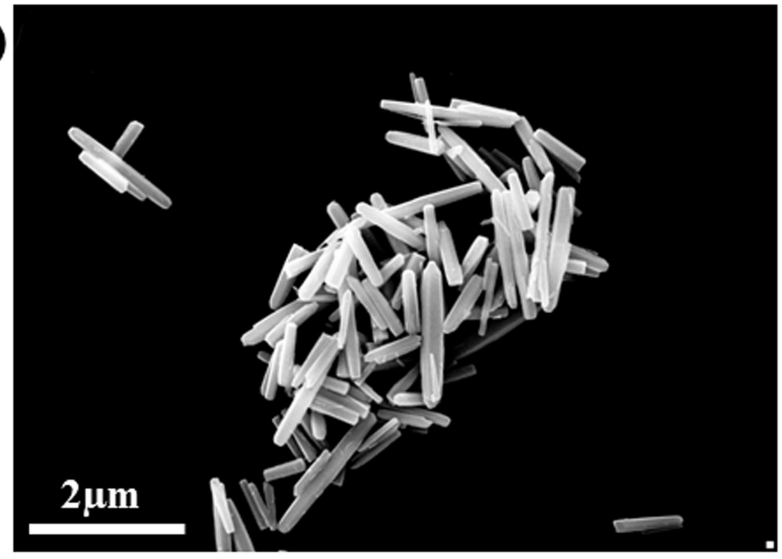

(b)

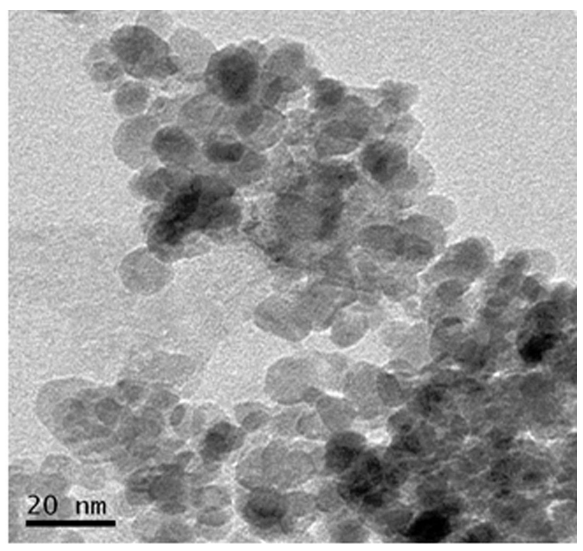

(d)

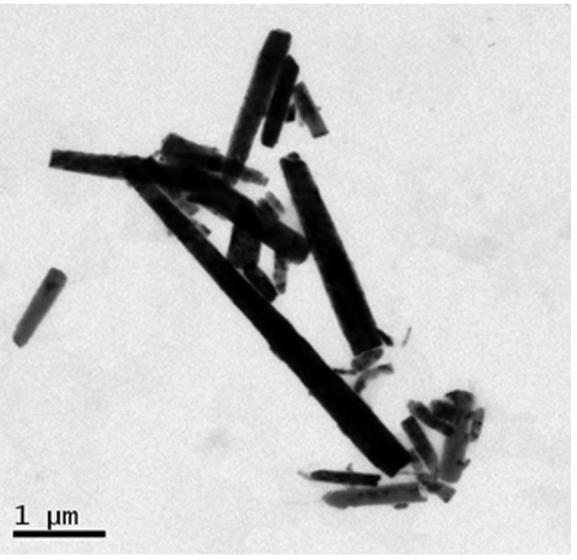

Figure 4: $(a, b)$ Microstructural FESEM and TEM bright field images of synthesized ZnO-P and (c,d) ZnO-R. 
(a)

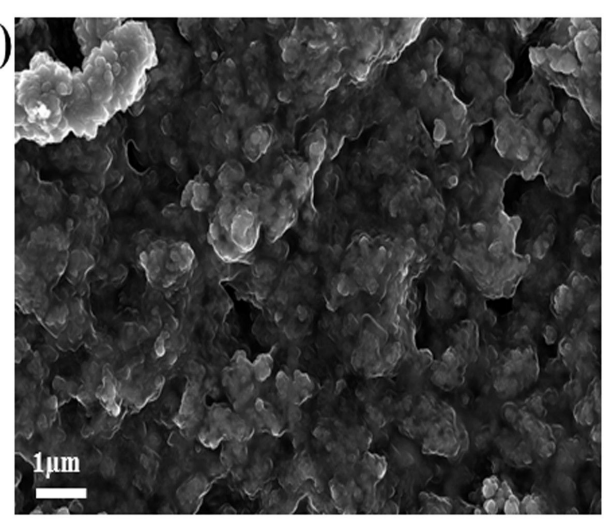

(c)

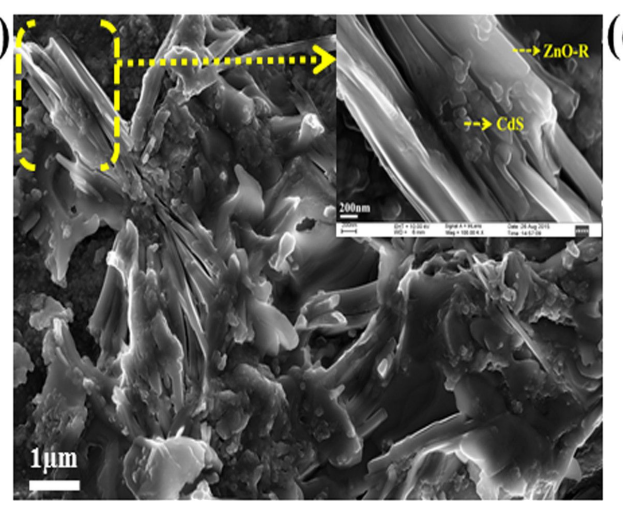

(b)

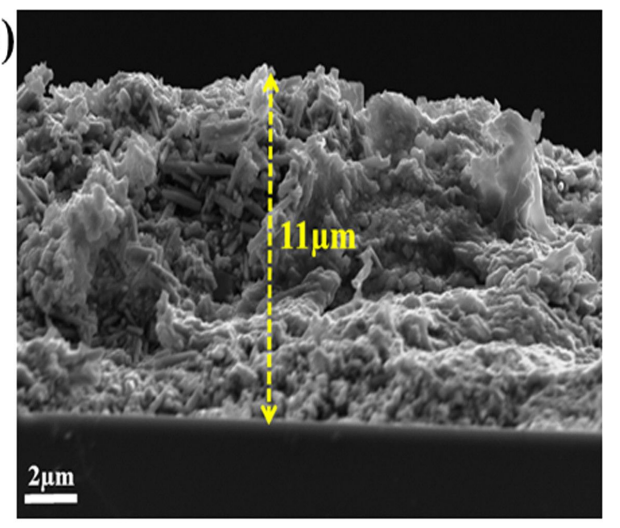

(d)

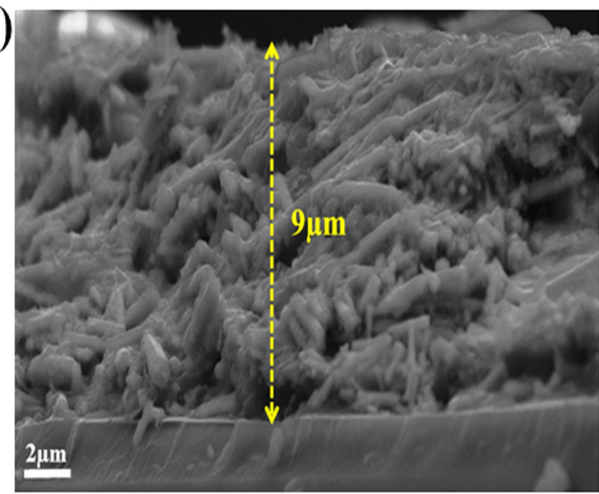

Figure 5: FESEM images of the surface and the corresponding cross-sectional view of CdS NP-sensitized ZnO-P-based film (a) and (b) and ZnO-R based film (c) and (d).
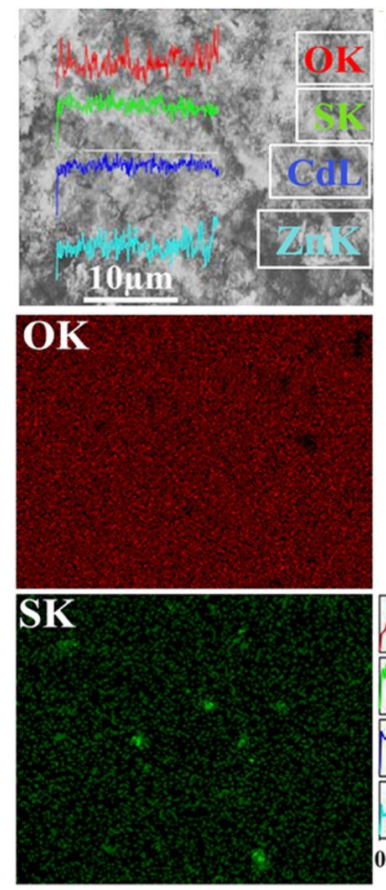

(a)
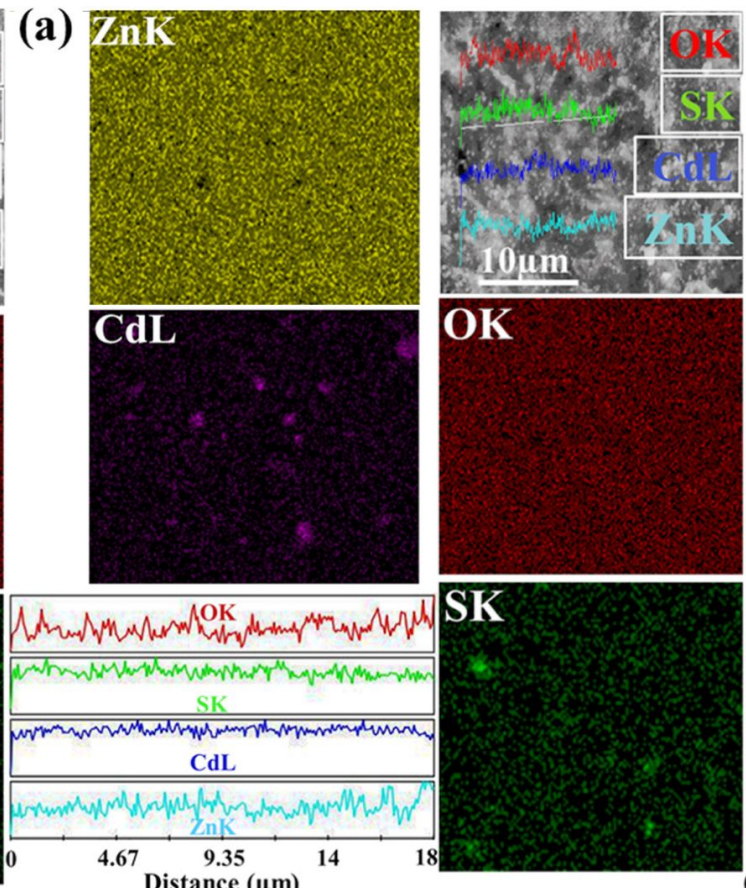

(b)
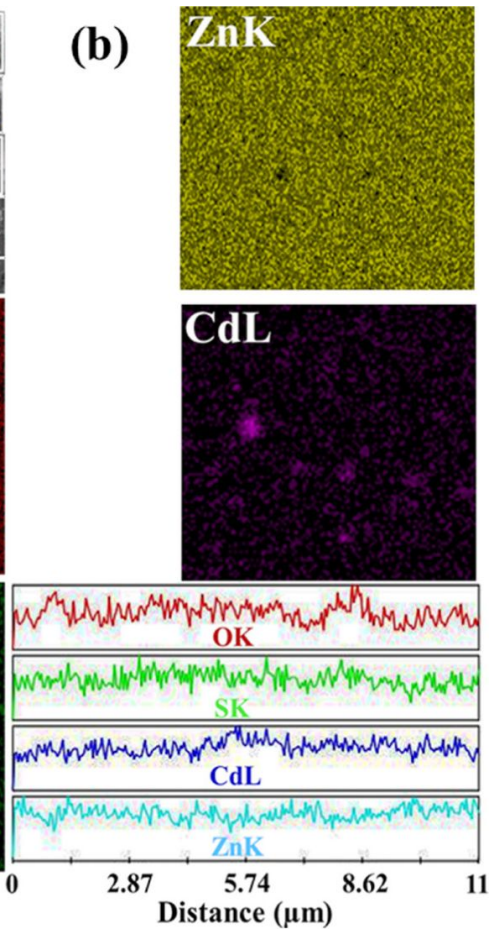

Figure 6: (a) and (b) FESEM elemental and line scale mapping of CdS-sensitized ZnO-P and ZnO-R films, respectively. 


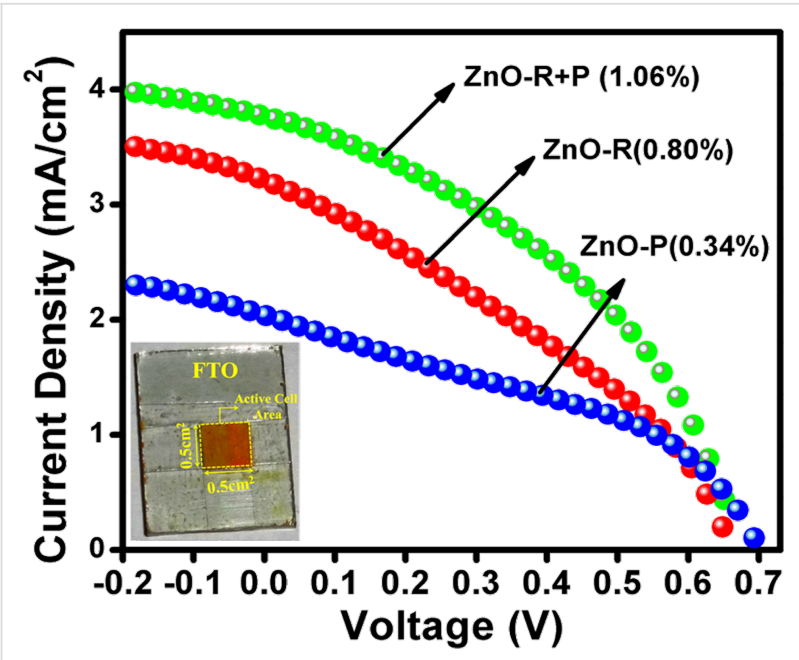

Figure 7: Current density $\left(\mathrm{mA} / \mathrm{cm}^{2}\right)$-voltage $(\mathrm{V})$ curve of CdS-sensitized $\mathrm{ZnO}-\mathrm{P}, \mathrm{ZnO}-\mathrm{R}$ and $\mathrm{ZnO}-\mathrm{R}+\mathrm{P}$ based cells. (Inset: digital image of the colloidal CdS sensitized $\mathrm{ZnO}-\mathrm{R}+\mathrm{P}$ film).

efficiency of $0.80 \%$. On the other hand, for QDSSC systems, the electrolyte and counter electrode combination is another important factor which affects the efficiency of the device. We have tested polysulphide as an electrolyte with a $\mathrm{Cu}_{2} \mathrm{~S}$ electrode exclusively for the above measurements. In order to monitor the effect of the popular $\mathrm{I}^{-} / \mathrm{I}_{3}{ }^{-}$electrolyte on the cell efficiency, for the CdS-sensitized $\mathrm{ZnO}-\mathrm{P}$ and $\mathrm{ZnO}-\mathrm{R}$ samples, the measurements were also carried out using $\mathrm{I}^{-} / \mathrm{I}_{3}{ }^{-}$electrolyte with an expensive Pt electrode as illustrated in Supporting Information File 1, Table S1. The efficiency is drastically varied upon replacement of the above system with the popular electrolyte. The redox potential of $\mathrm{S}^{2-} / \mathrm{S}_{x}{ }^{2-}$ and $\mathrm{I}^{-} / \mathrm{I}_{3}{ }^{-}$electrolyte is $-0.50 \mathrm{~V}$ and $-0.35 \mathrm{~V}$ vs NHE, respectively. In order to obtain a regenerative redox couple, a second element is needed to couple with $\mathrm{S}^{2-}$ from the $\mathrm{Na}_{2} \mathrm{~S}$. In most studies, sulfur is added to the sulfide salt to form a polysulfide $\left(\mathrm{S}^{2-} / \mathrm{S}_{x}{ }^{2-}\right)$ redox couple. From the above results it is evident that polysulphide electrolyte is more suitable for achieving better efficiency whereas the $\mathrm{I}^{-} / \mathrm{I}_{3}{ }^{-}$system is better suited for obtaining higher fill factors. The low value of fill factor obtained using the polysulphide electrolyte may be ascribed to the lower hole recovery rate of the polysulfide electrolyte, which leads to a higher probability for charge recombination and loss. In our case, the synthesized ZnO-P exhibits a weak, wide, visible emission from 500-700 $\mathrm{nm}$ upon excitation at $345 \mathrm{~nm}$ at room temperature as shown in Supporting Information File 1, Figure S4. The visible emission of $\mathrm{ZnO}$ basically arises from various surface defects, which can act as photogenerated electron trap states causing a loss of excited electrons [31]. Interestingly, the synthesized $\mathrm{ZnO}-\mathrm{R}$ does not exhibit any significant visible emission with respect to $\mathrm{ZnO}-\mathrm{P}$ at the same excitation wavelength. Therefore, we have introduced $\mathrm{ZnO}-\mathrm{R}$ as a scattering layer to overcome this issue. Thus, we have further fabricated cells employing nanoparticles as a blocking layer for better CdS sensitizing and nanorods as a scattering layer for pronounced light harvesting [31,32,41,42]. A significant enhancement in the photovoltaic performance has been noticed for the $\mathrm{ZnO}-\mathrm{P}+\mathrm{R}$ based cell exhibiting an efficiency of $1.06 \%$ (Figure 7), which is remarkably improved compared to ZnO-P. This gives $\approx 32 \%$ enhancement for overall efficiency compared to bare $\mathrm{ZnO}-\mathrm{R}$-based cells. In addition, a significant enhancement was noticed for the same film compared to bare $\mathrm{ZnO}-\mathrm{P}$ based film. This confirms the effective influence of nanorods as a scattering layer and nanoparticles in enhancing the photovoltaic performance of the colloidal CdS sensitized cells. The photovoltaic parameters have been collected in Table 1.

A similar set of experiments were carried out following the traditional SILAR process for in situ formation of CdS over ZnO-based films. The thickness of the films has been optimized to be same as for the CBD technique. A comparative study of the photovoltaic parameters for both the sensitization processes is collected in Table 1. Interestingly, a general trend of improvement in photovoltaic performance has been noticed for CBD compared to SILAR process. A probable electronic transition mechanism within the whole fabricated cell is proposed as follows:

In sensitizer:

$$
\mathrm{CdS}+h v \rightarrow \operatorname{CdS}\left(\mathrm{e}_{\mathrm{p}}+\mathrm{h}_{\mathrm{p}}\right)
$$

\begin{tabular}{|c|c|c|c|c|c|}
\hline Cell type & $V_{\text {oc }} \pm 0.02(\mathrm{~V})$ & $J_{\mathrm{sc}} \pm 0.01\left(\mathrm{~mA} / \mathrm{cm}^{2}\right)$ & $F F \pm 0.05(\%)$ & Efficiency $\pm 0.03(\%)$ & CdS form \\
\hline $\mathrm{ZnO}-\mathrm{P}$ & 0.68 & 2.00 & 24.88 & 0.34 & Colloidal CdS \\
\hline $\mathrm{ZnO}-\mathrm{R}$ & 0.66 & 3.48 & 34.13 & 0.80 & Colloidal CdS \\
\hline $\mathrm{ZnO}-\mathrm{R}+\mathrm{P}$ & 0.67 & 3.75 & 41.43 & 1.06 & Colloidal CdS \\
\hline $\mathrm{ZnO}-\mathrm{P}$ & 0.66 & 0.26 & 32.81 & 0.03 & SILAR CdS \\
\hline $\mathrm{ZnO}-\mathrm{R}$ & 0.73 & 1.03 & 30.42 & 0.23 & SILAR CdS \\
\hline $\mathrm{ZnO}-\mathrm{R}+\mathrm{P}$ & 0.70 & 2.54 & 40.19 & 0.75 & SILAR CdS \\
\hline
\end{tabular}




$$
\begin{gathered}
\operatorname{CdS}\left(\mathrm{e}_{\mathrm{p}}+\mathrm{h}_{\mathrm{p}}\right) \rightarrow \operatorname{CdS}\left(\mathrm{e}_{\mathrm{s}}+\mathrm{h}_{\mathrm{s}}\right) \\
\operatorname{CdS}\left(\mathrm{e}_{\mathrm{s}}+\mathrm{h}_{\mathrm{s}}\right) \rightarrow \operatorname{CdS}+h v
\end{gathered}
$$

At photoanode:

$$
\mathrm{CdS}\left(\mathrm{e}_{\mathrm{s}}+\mathrm{h}_{\mathrm{s}}\right)+\mathrm{ZnO} \rightarrow \mathrm{CdS}(\mathrm{h})+\mathrm{ZnO}(\mathrm{e})
$$

where the subscripts $\mathrm{s}$ and $\mathrm{p}$ refer to the electronic states of the electrons (e) and holes (h), respectively.

At electrolyte:

$$
\begin{gathered}
\mathrm{S}^{2-}+2 \mathrm{~h}^{+}(\mathrm{CdS}(\mathrm{h})) \rightarrow \mathrm{S} \\
\mathrm{S}+\mathrm{S}_{x-1}{ }^{2-} \rightarrow \mathrm{S}_{x}{ }^{2-}
\end{gathered}
$$

At counter electrode:

$$
\mathrm{S}_{x}^{2-}+2 \mathrm{e}^{-} \rightarrow \mathrm{S}_{x-1}{ }^{2-}+\mathrm{S}^{2-}
$$

In Table 2, the reported results on CdS-mediated cell performance are compared. Interestingly, a general trend of improvement in photovoltaic performance has been noticed for the $\mathrm{ZnO}$ nanorods and wires compared to other nanoforms. In comparison to the reported results on the QDSSCs based on $\mathrm{ZnO}$ photoanodes (Table 2), the results obtained in this work are quite competitive and interesting. In addition, the $V_{\mathrm{OC}}$ and $\mathrm{FF}$ of the measured cells are also higher compared to the literature results. This confirms the effectiveness of utilizing the BSAmediated CdS in improving the QDSSC performance with $\mathrm{ZnO}$ as photoanodes. The $I-V$ characteristics of the colloidal CdSsensitized $\mathrm{ZnO}-\mathrm{P}, \mathrm{ZnO}-\mathrm{R}$ and $\mathrm{ZnO}-\mathrm{R}+\mathrm{P}$ films measured within the bias voltage $-10 \mathrm{~V}$ to $+10 \mathrm{~V}$ in visible light is shown in Supporting Information File 1, Figure S3, exhibiting ohmic response. $I-V$ characteristics also sustain higher current generation for $1 \mathrm{D} \mathrm{ZnO}-\mathrm{R}$ than $\mathrm{ZnO}-\mathrm{P}$. Further, a significant enhancement in current was observed upon deposition of the nanorods over nanoparticles as $\mathrm{ZnO}-\mathrm{R}+\mathrm{P}$ shows better current conducting behavior for this particular system. As we have confirmed earlier, $\mathrm{ZnO}$ nanorods provided more channels for the fast transportation of the photoexcited electrons into the photoanodes, resulting in smaller probability of recombining leading to higher $V_{\mathrm{OC}}$ and $\mathrm{FF}$.

The X-ray diffraction pattern of the highest efficiency system, $\mathrm{ZnO}-\mathrm{R}+\mathrm{P}$ based $\mathrm{CdS}$ sensitized film, is shown in Figure 8a. It also indicates successful CdS sensitization over the film keeping the as-synthesized crystalline phase intact, and it is comparably higher than the $\mathrm{ZnO}-\mathrm{R}$ film alone. The corresponding FESEM microstructural surface and cross-sectional images are given in Figure 8b,c. From Figure 8b, the surface of the CdS sensitized $\mathrm{ZnO}-\mathrm{R}+\mathrm{P}$ film shows agglomerated nanorods with particles and there is a layer of CdS over them, indicating effective CdS sensitization. Furthermore, the thickness of the final cell was found to be $11.4 \mu \mathrm{m}$ from Figure $8 \mathrm{c}$, where it is clearly shown that nanorods are randomly distributed over the particle layers in the $\mathrm{ZnO}-\mathrm{R}+\mathrm{P}$ film. Again, the $\mathrm{CA}$ value was found to be $42.6^{\circ}$ (inset: Figure $8 \mathrm{c}$ ) which strongly supports a rodoriented film surface. The elemental mapping along with line scale mapping further confirms the homogeneous distribution of $\mathrm{CdS}$ throughout the $\mathrm{ZnO}-\mathrm{R}+\mathrm{P}$ surface, as illustrated in Figure 8d.

An overall mechanism of electron transport in colloidal CdS $\mathrm{ZnO}$ based solar cells is illustrated schematically in Figure 9. After excitation, the basic electron conduction and regeneration throughout the cell involves the following steps (1) electron

\begin{tabular}{lllll}
\hline $\begin{array}{l}\text { Table 2: Reported performance of CdS-sensitized ZnO-based solar cells. } \\
\text { Photoanode }\end{array}$ & CdS sensitizing process & Fill factor (\%) & Efficiency (\%) & Reference \\
\hline ZnO NPs & SILAR & 29.70 & 0.067 & {$[10]$} \\
ZnO nanowire & SILAR & 31.49 & 3.53 & {$[43]$} \\
Porous ZnO nanosheets & SILAR & 28.00 & 1.16 & {$[44]$} \\
ZnO NPs & SILAR & 30.00 & 0.85 & {$[13]$} \\
ZnO nanowire & CBD & 29.72 & 0.34 & {$[14]$} \\
ZnO nanorod & Electrodeposition & 34.40 & 1.07 & {$[45]$} \\
ZnO nanorod array & CBD & 27.00 & 0.29 & {$[46]$} \\
ZnO & SPD & 33.00 & 1.54 & {$[47]$} \\
ZnO nanorod & Post-deposition & 34.13 & 0.80 & current work \\
ZnO nanorod/nanoparticle & Post-deposition & 41.43 & 1.06 & current work
\end{tabular}


(a)

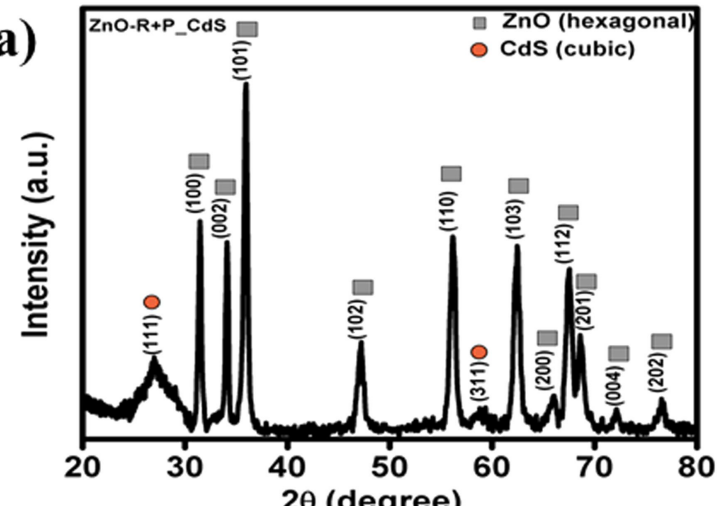

(b)

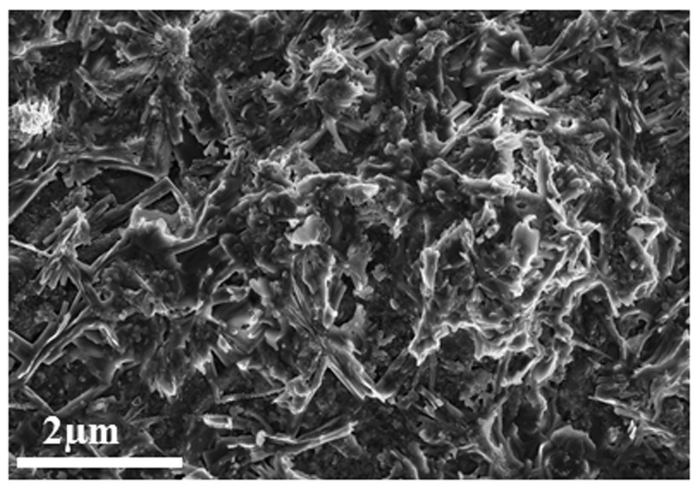

OK SK CdL ZnK (c)

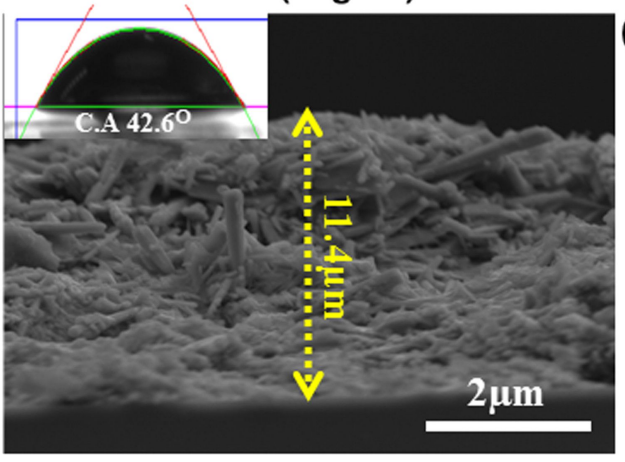

(d)
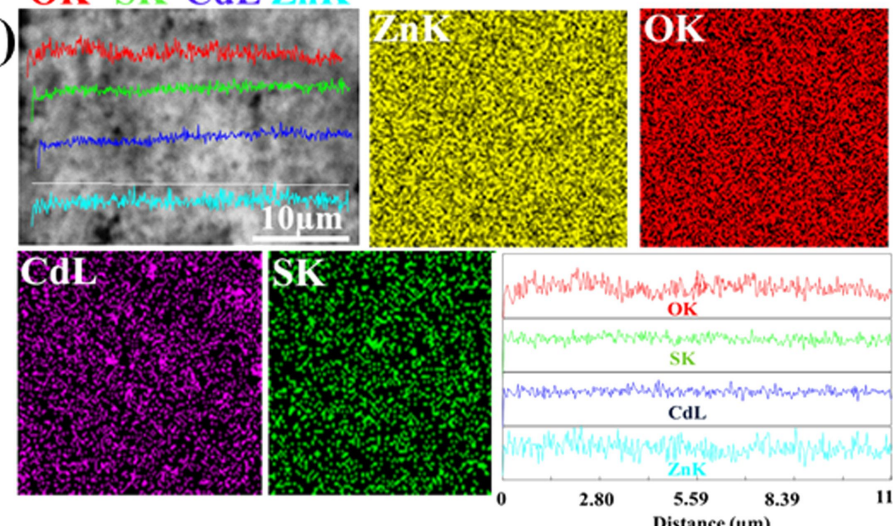

Figure 8: (a) X-ray diffraction pattern of the colloidal CdS sensitized ZnO-R+P based film, (b) corresponding FESEM microstructural image, (c) crosssectional view of the same film (inset: digital image of CdS contact angle measurement), (d) elemental and line mapping images of the same film.
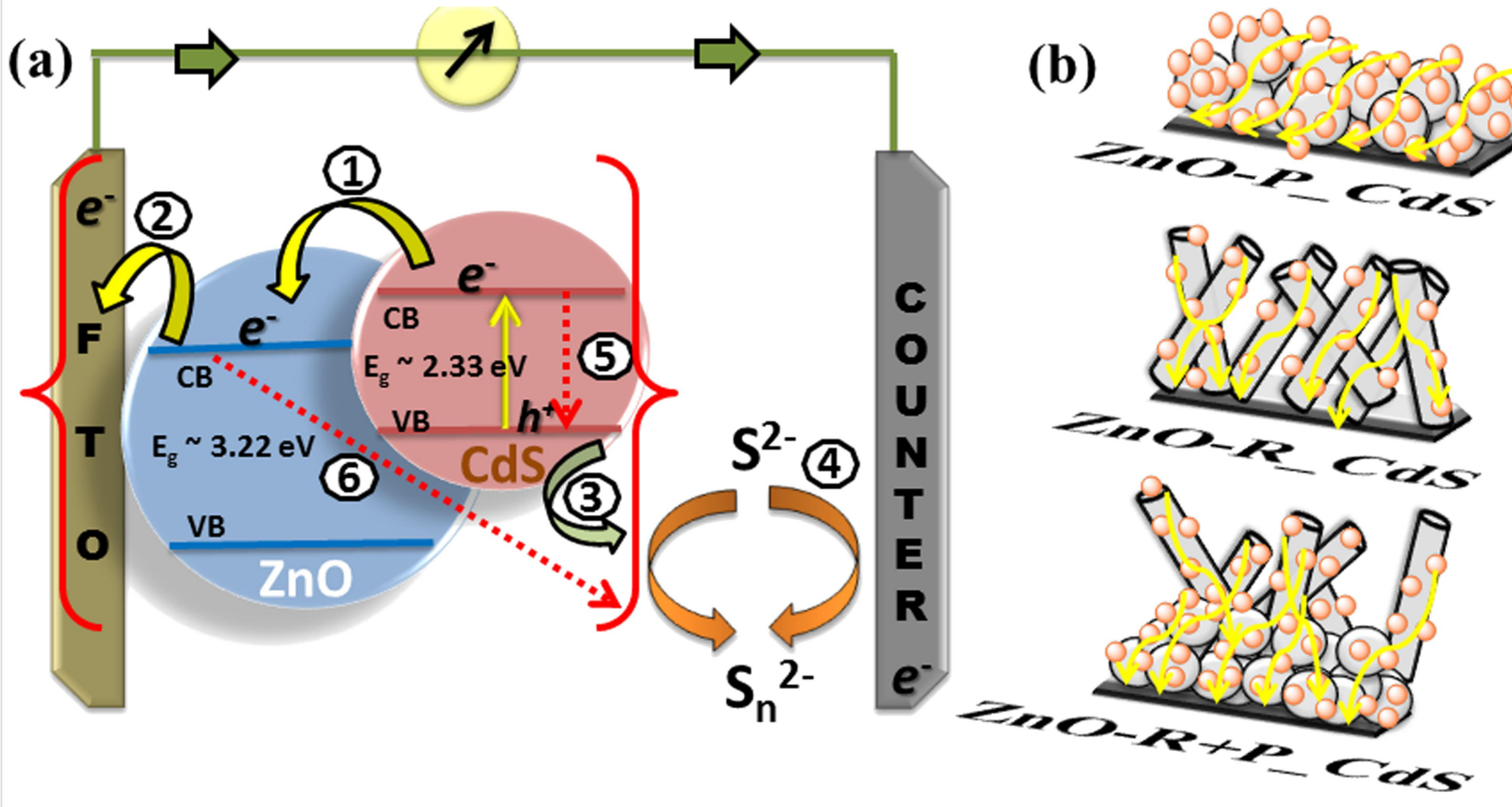

Figure 9: (a) and (b) Schematic representation of ZnO/CdS-based QDSSC cell basic operation principal and probable electron conduction pathways for colloidal CdS-sensitized ZnO-P, ZnO-P and ZnO-R+P-based solar cells. 
injection towards $\mathrm{ZnO}$, (2) electron hopping towards FTO, (3) hole recombination, (4) electron regeneration (5) and (6) recombination of electron, as represented in Figure 9a. We have looked into the probable pathway for electron conduction through the different $\mathrm{ZnO}$-based $(\mathrm{P}, \mathrm{R}, \mathrm{R}+\mathrm{P}$ ) photoanodes sensitized with colloidal CdS NPs, as schematically represented in Figure $9 \mathrm{~b}$. As stated previously, due to the higher surface area of the nanoparticles, more CdS was loaded on them than on the nanorods but uncontrolled agglomeration may result in random electron conduction and further may enhance the recombination rate. Whereas, the nanorods (due to their superior onedimensional structure and reduced grain boundaries) are expected to favor a direct conduction pathway for rapid electron transport. In the case of $\mathrm{ZnO}-\mathrm{R}+\mathrm{P}$ based films, the higher $\mathrm{CdS}$ loading property of $\mathrm{ZnO}-\mathrm{P}$ and the superior one-dimensional nature of $\mathrm{ZnO}-\mathrm{R}$ has together enhanced the overall QDSSC performance compared to their individual systems.

In situ synthesis and deposition of QDs by the chemical bath deposition (CBD) or successive ionic layer adsorption and reaction (SILAR) method leads to the direct growth of QDs onto the electrode material surface by the chemical reaction of respective ionic species [48-50]. In order to understand the difference in the processing conditions, we further carried out experiments with the SILAR method also as shown in Table 1. In the CBD process, we have used the colloidal CdS synthesized by BSA templating which is anticipated to act as a functional linker to the electrode material surface. In spite of various optimizations in terms of varying the morphology of the used photoanodes, the use of surface functionalized CdS colloids, deposition techniques such as SILAR and CBD using the colloidal dispersion, and different types of electrolytes, the overall conversion efficiency of the fabricated cells could not be enhanced above $1 \%$. However, the efficiency and the fill factor exhibited by our system is still comparable to most of the reports on $\mathrm{ZnO} / \mathrm{CdS}$ systems. The probable reasons for the low efficiency and low FF in our systems are (i) presence of large number of unpassivated or partially passivated surface states as confirmed from emission characteristics and (ii) an ex situ colloidal CdS sensitization linking approach was implemented which has the advantage of controlling the properties of the CdS sensitizer through its size and shape, but may lead to more special distance between the QD and the photoelectrode surface and (iii) poor fill factors of the as-prepared DSSC devices.

\section{Conclusion}

Colloidal CdS NPs have been synthesized through a bioinspired route using bovine serum albumin as a template. The structural, microstructural and optical studies confirmed the formation of phase pure cubic CdS NPs with average nanoparticle size of $\approx 5 \mathrm{~nm}$ with improved optical properties. The synthe- sized CdS NPs have been utilized as an alternative and costeffective sensitizer for $\mathrm{ZnO}$-based photoanodes. Various structural and microstructural analyses of the fabricated films further ascertain the successful sensitization of the synthesized colloidal CdS NPs. The photovoltaic performance has been monitored for the QDSSCs using $\mathrm{ZnO}$ nanoparticles, $\mathrm{ZnO}$ nanorods and a $\mathrm{ZnO}$ nanoparticle/nanorod mixture as photoanode materials and the synthesized CdS NPs as sensitizer. A maximum efficiency of $1.06 \%$ has been achieved in case of the $\mathrm{ZnO}-\mathrm{P}+\mathrm{R}$ based cell where $\mathrm{ZnO}-\mathrm{P}$ acts as a blocking layer for better $\mathrm{CdS}$ sensitizing and $\mathrm{ZnO}-\mathrm{R}$ has been introduced as a scattering layer for pronounced light harvesting.

\section{Supporting Information}

\section{Supporting Information File 1}

Additional Experimental Information. Quantitative EDAX spectrum and zeta potential measurement of synthesized colloidal CdS, $I-V$ characteristics CdS-sensitized ZnO-P, $\mathrm{ZnO}-\mathrm{R}$ and $\mathrm{ZnO}-\mathrm{R}+\mathrm{P}$ films, emission data on films and a table with performance details on different electrolytes. [http://www.beilstein-journals.org/bjnano/content/ supplementary/2190-4286-8-23-S1.pdf]

\section{Acknowledgement}

AR gratefully acknowledges the INSPIRE programme of the Department of Science and Technology, Govt. of India for awarding a junior research fellowship. PSD acknowledges MNRE for financial support under the CSIR-TAPSUN programme (GAP 0339).

\section{References}

1. Rühle, S.; Shalom, M.; Zaban, A. ChemPhysChem 2010, 11, 2290-2304. doi:10.1002/cphc.201000069

2. Tian, J.; Cao, G. Nano Rev. 2013, 4, 22578-22587. doi:10.3402/nano.v4i0.22578

3. Salant, A.; Shalom, M.; Hod, I.; Faust, A.; Zaban, A.; Banin, U. ACS Nano 2010, 4, 5962-5968. doi:10.1021/nn1018208

4. Kamat, P. V. J. Phys. Chem. Lett. 2013, 4, 908-918. doi:10.1021/jz400052e

5. Jun, H. K.; Careem, M. A.; Arof, A. K. Renewable Sustainable Energy Rev. 2013, 22, 148-167. doi:10.1016/j.rser.2013.01.030

6. Kamat, P. V. J. Phys. Chem. C 2008, 112, 18737-18753. doi:10.1021/jp806791s

7. Kim, M. R.; Mar, D. J. Phys. Chem. Lett. 2015, 6, 85-99. doi:10.1021/jz502227h

8. Tian, J.; Cao, G. Nano Rev. 2013, 4, 2578.

9. Duan, J.; Zhang, H.; Tang, Q.; He, B.; Yu, L. J. Mater. Chem. A 2015, 3, 17497-17510. doi:10.1039/C5TA03280F

10. Li, C.; Yang, L.; Xiao, J.; Wu, Y.-C.; Søndergaard, M.; Luo, Y.; Li, D.; Meng, Q.; Iversen, B. B. Phys. Chem. Chem. Phys. 2013, 15, 8710-8715. doi:10.1039/C3CP50365H 
11. Liu, H.; Zhang, G.; Sun, W.; Shen, Z.; Shi, M. PLoS One 2015, 10 , e0138298. doi:10.1371/journal.pone.0138298

12. Poornima, K.; Gopala Krishnan, K.; Lalitha, B.; Raja, M. Superlattices Microstruct. 2015, 83, 147-156. doi:10.1016/j.spmi.2015.03.011

13. Ganesh, T.; Mane, R. S.; Cai, G.; Chang, J.-H.; Han, S.-H. J. Phys. Chem. C 2009, 113, 7666-7669. doi:10.1021/jp901224n

14. Zhang, Y.; Xie, T.; Jiang, J.; Wei, X.; Pang, S.; Wang, S.; Wang, D. Nanotechnology 2009, 20, 155707. doi:10.1088/0957-4484/20/15/155707

15. Qi, J.; Liu, W.; Biswas, C.; Zhang, G.; Sun, L.; Wang, Z.; Hu, X.; Zhang, Y. Opt. Commun. 2015, 349, 198-202. doi:10.1016/j.optcom.2015.03.060

16. Zhao, Y.; Guo, H.; Hua, H.; Xi, Y.; Hu, C. Electrochim. Acta 2014, 115, 487-492. doi:10.1016/j.electacta.2013.10.205

17. Zhang, P.; Gao, L. Langmuir 2003, 19, 208-210. doi:10.1021/la0206458

18. Wei, H. H.-Y.; Evans, C. M.; Swartz, B. D.; Neukirch, A. J.; Young, J.; Prezhdo, O. V.; Krauss, T. D. Nano Lett. 2012, 12, 4465-4471. doi:10.1021/nl3012962

19. Duxin, N.; Liu, F.; Vali, H.; Eisenberg, A. J. Am. Chem. Soc. 2005, 127, 10063-10069. doi:10.1021/ja0505043

20. Ma, N.; Sargent, E. H.; Kelley, S. O. J. Mater. Chem. 2008, 18 , 954-964. doi:10.1039/B711764G

21. Baláž, M.; Baláž, P.; Sayagués, M. J.; Zorkovská, A. Mater. Sci. Semicond. Process. 2013, 16, 1899-1903. doi:10.1016/j.mssp.2013.06.024

22. Tripathi, R. M.; Bhadwal, A. S.; Singh, P.; Shrivastav, A.; Singh, M. P.; Shrivastav, B. R. Adv. Nat. Sci.: Nanosci. Nanotechnol. 2014, 5 , 025006. doi:10.1088/2043-6262/5/2/025006

23. Su, H.; Han, J.; Dong, Q.; Zhang, D.; Guo, Q. Nanotechnology 2008, 19, 025601. doi:10.1088/0957-4484/19/02/025601

24. Naveenraj, S.; Asiri, A. M.; Anandan, S. J. Nanopart. Res. 2013, 15 , 1671-1682. doi:10.1007/s11051-013-1671-9

25. Liang, J.-g.; Ai, X.-p.; He, Z.-k.; Xie, H.-y.; Pang, D.-w. Mater. Lett. 2005, 59, 2778-2781. doi:10.1016/j.matlet.2005.04.024

26. Jhonsi, M. A.; Kathiravan, A.; Renganathan, R. Colloids Surf., B 2009, 72, 167-172. doi:10.1016/j.colsurfb.2009.03.030

27. Na, W.; Liu, X.; Hu, T.; Su, X. New J. Chem. 2016, 40, 1872-1877. doi:10.1039/C5NJ03117F

28. Hagfeldt, A.; Boschloo, G.; Sun, L.; Kloo, L.; Pattersson, H. Chem. Rev. 2010, 110, 6595-6668. doi:10.1021/cr900356p

29. Zhang, Q.; Dandeneau, C. S.; Zhou, X.; Guozhong, C. Adv. Mater. 2009, 21, 4087-4121. doi:10.1002/adma.200803827

30. Lee, W.; Min, S. K.; Dhas, V.; Ogale, S. B.; Han, S.-H. Electrochem. Commun. 2009, 11, 103-106. doi:10.1016/j.elecom.2008.10.042

31. Das, P. P.; Agarkar, S. A.; Mukhopadhyay, S.; Manju, U.; Ogale, S. B.; Devi, P. S. Inorg. Chem. 2014, 53, 3961-3972. doi:10.1021/ic500279q

32. Das, P. P.; Mukhopadhyay, S.; Agarkar, S. A.; Jana, A.; Devi, P. S. Solid State Sci. 2015, 48, 237-243. doi:10.1016/j.solidstatesciences.2015.08.014

33. Das, P. P.; Roy, A.; Das, S.; Devi, P. S. Phys. Chem. Chem. Phys. 2016, 18, 1429-1438. doi:10.1039/C5CP04716A

34. Lee, Y.-L.; Chang, C.-H. J. Power Sources 2008, 185, 584-588. doi:10.1016/j.jpowsour.2008.07.014

35. Yang, Z.; Chen, C.-Y.; Liu, C.-W.; Chang, H.-T. Chem. Commun. 2010, 46, 5485-5487. doi:10.1039/C0CC00642D

36. Jiang, J.; He, Y.; Wan, L.; Cui, Z.; Cuia, Z.; Jessop, P. G. Chem. Commun. 2013, 49, 1912-1914. doi:10.1039/C2CC38202D
37. Dai, Z.; Zhang, J.; Bao, J.; Huang, X.; Mo, X. J. Mater. Chem. 2007, 17, 1087-1093. doi:10.1039/B614203F

38. Malashchonak, M. V.; Poznyak, S. K.; Streltsov, E. A.; Kulak, A. I.; Korolik, O. V.; Mazanik, A. V. Beilstein J. Nanotechnol. 2013, 4, 255-261. doi:10.3762/bjnano.4.27

39. Mandal, A.; Saha, J.; De, G. Opt. Mater. 2011, 34, 6-11. doi:10.1016/j.optmat.2011.07.019

40. Murawala, P.; Phandis, S. M.; Bhonde, R. R.; Prasad, B. L. V. Colloids Surf., B 2009, 73, 224-228. doi:10.1016/j.colsurfb.2009.05.029

41. Jana, A.; Das, P. P.; Agarkar, S. A.; Devi, P. S. Sol. Energy 2014, 102, 143-151. doi:10.1016/j.solener.2014.01.011

42. Uthirakumar, P.; Kang, J. H.; Senthilarasu, S.; Hong, C.-H. Physica E 2011, 43, 1746-1750. doi:10.1016/j.physe.2011.06.001

43. Tak, Y.; Hong, S. J.; Lee, J. S.; Kijung, Y. J. Mater. Chem. 2009, 19, 5945-5951. doi:10.1039/B904993B

44. Chen, H.; Li, W.; Liu, H.; Zhu, L. Electrochem. Commun. 2011, 13 , 331-334. doi:10.1016/j.elecom.2011.01.017

45. Yao, C.-Z.; Wei, B.-H.; Meng, L.-X.; Li, H.; Gong, Q.-J.; Sun, H.; Ma, H.-X.; Hu, X.-H. J. Power Sources 2012, 207, 222-228. doi:10.1016/j.jpowsour.2012.01.154

46. Luan, C.; Vaneski, A.; Susha, A. S.; Xu, X.; Wang, H.-E.; Chen, X.; Xu, J.; Zhang, W.; Lee, C.-S.; Rogach, A. L.; Zapien, J. A. Nanoscale Res. Lett. 2011, 6, 340. doi:10.1186/1556-276X-6-340

47. Zhu, G.; Lv, T.; Pan, L.; Sun, Z.; Sun, C. J. Alloys Compd. 2011, 509, 362-365. doi:10.1016/j.jallcom.2010.09.026

48. Hod, I.; González-Pedro, V.; Tachan, Z.; Fabregat-Santiago, F.; Mora-Seró, I.; Bisquert, J.; Zaban, A. J. Phys. Chem. Lett. 2011, 2, 3032-3035. doi:10.1021/jz201417f

49. Seou, M.; Kim, H.; Tak, Y.; Yong, K. Chem. Commun. 2010, 46, 5521-5523. doi:10.1039/c0cc00542h

50. Hodes, G. J. Phys. Chem. C 2008, 112, 17778-17787. doi:10.1021/jp803310s

\section{License and Terms}

This is an Open Access article under the terms of the Creative Commons Attribution License (http://creativecommons.org/licenses/by/4.0), which permits unrestricted use, distribution, and reproduction in any medium, provided the original work is properly cited.

The license is subject to the Beilstein Journal of Nanotechnology terms and conditions: (http://www.beilstein-journals.org/bjnano)

The definitive version of this article is the electronic one which can be found at: $\underline{\text { doi:10.3762/bjnano.8.23 }}$ 